Sosyo

Ekonomi

\title{
Türkiye’de Cari Açığın Belirleyicilerinin Ampirik Analizi
}

Aydanur GACENER ATIŞ

aydanur.gacener@ege.edu.tr
Fatih SAYGILI

fatih.saygili@ege.edu.tr

\section{An Empirical Analysis of Determinants of the Current Account Deficit in Turkey}

\begin{abstract}
The purpose of this study is to identify the determinants of the current account deficit in Turkey and to analyze the relationship between explanatory variables and the current account deficit. The analyses in this paper, aim to determine possible short and long terms effects of these variables on the current account. Quarterly data of CBT Electronic Data Distribution System is used for the period of 1998:1-2013:1 to estimate the results. Our findings indicate that the most significant determinants of Turkey's current account deficit are the growth rate and the terms of trade.
\end{abstract}

Keywords

: Current Account Deficit, Cointegration, Vector Error Corection Model, Granger Causality.

JEL Classification Codes : $\quad$ F30, F32, C50.

\section{Özet}

Bu çalışmanın amacı, Türkiye'de cari açığın gelişiminde etkili olan ya da bunu açıklayan değişkenlerin belirlenmesi ve aralarındaki ilişkilerin analiz edilmesidir. Bu çalışmadaki analizler, söz konusu değişkenlerin cari açık üzerindeki olası kısa ve uzun dönemli etkilerini belirlemeye yöneliktir. Bu ilişkilerin tahminlenmesinde, TCMB'nin Elektronik Veri Dağıtım Sistemi'nden sağlanan; 1998:1-2013:1 dönemi çeyrekli verileri kullanılmıştır. Bulgularımız, Türkiye'nin cari açığının en önemli belirleyicilerinin büyüme oranı ve dış ticaret hadleri olduğunu ortaya koymaktadır.

Anahtar Sözcükler $\quad$ : Cari Açık, Eşbütünleşme, Vektör Hata Düzeltme Modeli, Granger Nedensellik. 
Aydanur GACENER ATIŞ \& Fatih SAYGILI 


\section{Giriş}

Son çeyrek yüzyılda özellikle gelişmekte olan ülkelerin ekonomi alanındaki temel sorunlarından biri cari açıktır. Bu açık döviz cinsinden gelir ve giderler arasındaki (mal ve hizmet ticareti, gelirler ve transferler) ülke aleyhine farkı yansıtmaktadır. $\mathrm{Bu}$ açığın nedenlerinin belirlenmesi, bu etkenlere ilişkin önlemlerin alınması ve politik yaklaşımların geliştirilmesine olanak sağlar. Ancak konunun sadece nedensel yönünün ele alınması çözüm olanaklarını kısıtlayacağından, aynı zamanda bu açığın nasıl finanse edildiğinin de dikkate alınması gerekir. Aslında bu sorun, gelişmekte olan ülkelerin tasarruf açıklarının varlığı, harcama yönlü iç ve dış politikalar ile gelir yaratan mekanizmaların sürdürülememesi sonucu ortaya çıkmaktadır.

Cari açık ekonomik istikrarsızlığın göstergelerinden biri olarak da kabul edilmektedir. 1990'lı yıllarda birçok ülkede ortaya çıkan cari açık sorunu, özellikle gelişmekte olan ülkeler açısından ekonomik krizlerin en önemli nedenlerinden biri olarak kabul edilmiştir (Dornbusch ve Fischer, 1990; Freund, 2000; Labonte, 2005). Cari açığın bir kriz sinyali olarak kabul edilmesiyle ilgili tartışmalar da bu yıllarda başlamıştır. Dornbusch ve Fischer (1990), cari açığın, GSYH'ye oranının \%4, Freund (2000) ise \%5 olmasını bir eşik değer olarak tanımlamış ve bu değerin aşılmasını, kriz sinyali olarak kabul etmişlerdir. Labonte'ye (2005) göre; Meksika, Türkiye, Doğu Asya, Brezilya, Arjantin gibi gelişmekte olan ülkelerde büyük cari açıklar, finans ve döviz krizleri için en önemli öncü göstergedir. $\mathrm{Bu}$ ülkelerde cari işlemler hesabı, ekonomik istikrarın sürdürülebilirliği açısından, oldukça önemlidir (Göçer, 2013: 214).

Türkiye'nin cari açık sorunu GSYH'deki payı açısından ele alındığında, yukarıda bahsi geçen ve bu büyüklük için eşik değer olarak kabul edilen \%4, $2000 \mathrm{Kasım}-$ 2001 Şubat döneminde bir miktar aşıldığından, sinyal olarak algılanmıştır. 2001-2003 dönemi cari açık sorununun göreli olarak azaldığı bir süreçtir. Bu dönemde uygulanmaya başlanan Güçlü Ekonomiye Geçiş programı ile elde edilen sonuçların makroekonomik göstergelere yansımaları cari açığın GSYH'deki payını da azaltmıştır. Bunun temel unsurlarından biri esnek döviz kuru uygulamasına geçişle birlikte, TL'nin aşırı değer kazanmasıdır. Göreli olarak ucuzlayan ithal mal ve hizmetlere yönelik talep artışı, yanı sıra ihracatın ve ekonomik büyümenin büyük oranda ithal girdiler yoluyla sağlanması cari açı̆̆ın giderek artmasına neden olmuştur.

Grafik: 1'den izlenebileceği gibi, -2009-2011 dönemi hariç- 2003 yılından sonra cari açığın payı sürekli artmıştır. Özellikle 2002 yılından sonra TL'nin değer kazanmaya başlaması sonucu 2003 yılında 7,5 milyar dolar olan cari açık, 2007'de 37,8 milyar dolara, 2010 y1lında 45,5 milyar dolara (GSYH'ye oranı \%6,2), 2011 yılında da 75 milyar dolara (GSYH'ye oranı \%9,7) yükselmiştir. Yurtiçi tüketim artışının ithal mallara yönelmesi cari açı̆̆ın bu denli artmasında etkili olmuştur. 
2009-2011 yılları Avrupa kıtası ve ABD'de yaşanan küresel krizin olumsuz etkilerinin yansıdığı bir süreçtir. Bu ülkeler, kriz nedeniyle satın alma güçlerindeki gerilemeyi, doğrudan ihraç mallarımıza yönelik taleplerini azaltarak göstermişlerdir. $\mathrm{Bu}$ etkileşim kuşkusuz reel kesimin üretim hacminin daralmasına neden olmuştur. Bu açıdan Türkiye'nin hem büyüme oranı hem de buna bağlı satın alma gücü azaldığından, ithal mal talebi de gerilemiştir. Dolayısıyla bu süreçte cari açık bir miktar toparlanmıştır. Ancak bunu izleyen yıl, cari açığın dönem boyunca en fazla derinleştiği ve kötüleştiği dönemdir.

Grafik 1: Cari Açığın GSYH'deki Payı (mevsimsel etkilerden arındırılmış) (\%)

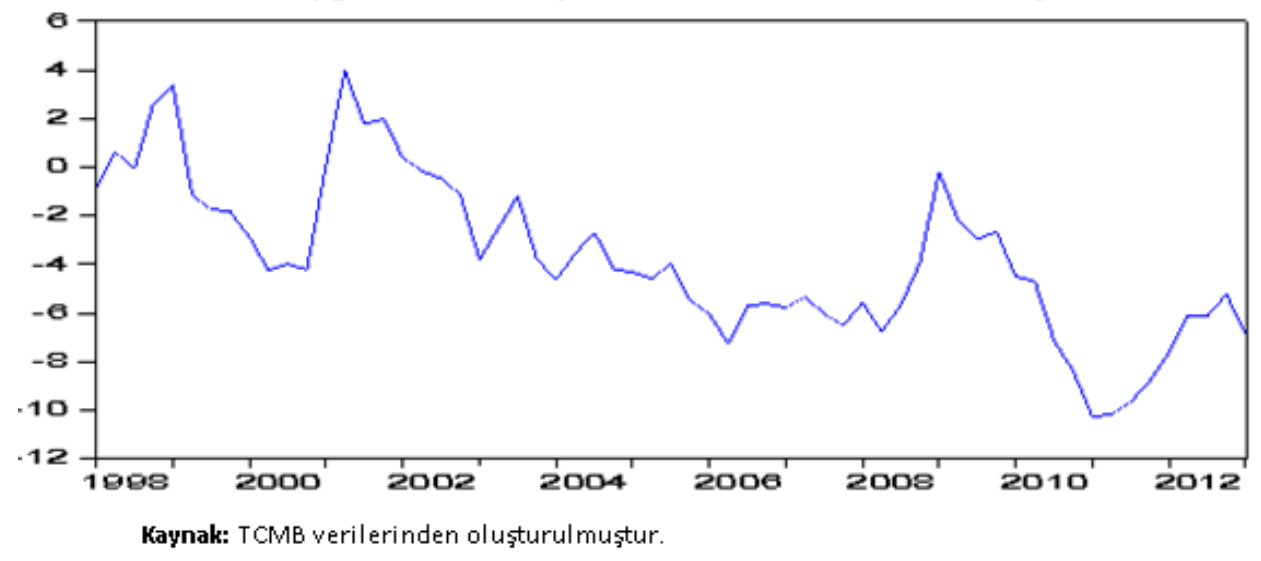

TCMB, 2010 yılında kredi hacmindeki artış ve TL'nin aşırı değer kazanmasına bağlı olarak, cari dengenin bozulma eğilimine girmesi üzerine 2010 yılının sonlarından itibaren makro finansal risklerin azaltılması konusuna odaklanmıştır. Cari dengedeki bozulmayı kontrol altına almak ve ekonomiyi sağlıklı bir büyüme kompozisyonuna kavuşturmak için kredi büyümesinin yavaşlatılması ve TL'nin iktisadi temellere uyumlu hale getirilmesi amaçlanmıştır. Kredilerin yavaşlatılması konusunda diğer otoritelerle eş güdüm halinde zorunlu karşılık oranları, likidite politikası gibi politika araçları kullanılmıştır. TL'deki aşırı değerleme, politika faiz oranları düşürülerek ve faiz koridoru aşağı yönlü genişletilerek giderilmiştir. Uygulanan politikalar sonrasında krediler tarafında da arzu edilen sonuçlar büyük ölçüde alınmış; kredi büyümesi yavaşlamıştır (Kara, 2012: 19). Bu gelişmeler sonucunda da cari açığın pay1 \%10'dan, \%6'ya kadar gerilemiştir.

Türkiye'de cari açığın gelişimine yönelik bu açıklamalar ışığında çalışmada, cari açı değişkeni üzerinde etkili olan ya da bunu açılayan değişkenlerin belirlenmesi söz konusudur. $\mathrm{Bu}$ konuya ilişkin yazında yer alan çok sayıdaki araştırmada genel itibariyle değişkenler arası ilişkiler nedensellik bağlamında ele alınmıştır. Bu çalışmada ise, nedensellik ilişkisinin yönünün belirlenmesinin yanı sıra, ayrıca değişkenler arasındaki 
ilişki uzun ve kısa dönemli etkileşimleri ortaya koymak açısından modellenmiştir. Ancak söz konusu değişkenlerin belirlenmesi aşamasında, ülkemizin enerji kaynaklarına yönelik dışa bağımlılığın yüksek olması nedeniyle, bu büyüklükle ilgili değişkenlerin baskınlığı dikkate alınarak, model dışında tutulmaları uygun görülmüştür.

Buna göre çalışma beş bölümden oluşmaktadır. Giriş bölümünde cari açığın önemi ve Türkiye'deki gelişimi vurgulanmıştır. İkinci bölümde yazında cari açığın nedenleri, bu açığı belirleyen unsurları dikkate alan uygulamalı çalışmalar incelenmiştir. Yazında konunun değişik yönlerden ele alınmış olması çok sayıda çalışmanın yapılmasına neden olmuştur. Bununla birlikte, esas olarak konumuzun sınırları dâhilinde yani cari açığın belirleyenlerinin modellenmesine yönelik çalışmalar ele alınmıştır. Çalışmada kullanılan modelleme tekniği üçüncü bölümde tanıtılmış; izleyen bölümde araştırma bulgularına yer verilmiş; son bölümde ise bulgular çerçevesinde genel bir değerlendirme yapılmıştır.

\section{Yazın Taraması}

$\mathrm{Bu}$ bölümde yazında cari açığın nedenleri ve belirleyenlerini dikkate alan uygulamalı çalışmalar incelenmiştir. Yazında konunun değişik açılardan (nedensellik, finansmanı, sürdürülebilirlik) ele alınmış olması birçok çalışmanın yapılmasına olanak sağlamışır. Ancak bu bölümde, ele aldığımız konu dâhilinde yani cari açığın belirleyenlerinin modellenmesine yönelik çalışmalara yer verilmiştir. Buna göre;

Yücel'in (2003), 1980 sonrasını araştırmak amacıyla Türkiye ekonomisi için yaptığı çalışmada büyüme oranı, döviz kuru, dış ticaret hadleri ve Merkez Bankası rezervleri cari dengede ortaya çıkan değişiklikleri açıklamakta istatistikî olarak anlamlı bulunmuş̧ur.

Erkılıç (2006), Türkiye'de cari açığın belirleyicileri üzerine yaptıkları ampirik çalışmada, en önemli ve istatistiki olarak anlamlı olan değişkenlerin; bir dönem önceki cari açık, reel döviz kuru ve büyüme oranı olduğunu tespit etmişlerdir.

Çakman ve Çakmak'ın (2007) çalışmalarında, cari işlemler dengesi (cari işlemler dengesi/GSMH), büyüme ve reel kur endeksinin yanı sıra beş yapısal faktörün bir fonksiyonu olarak tanımlanmıştır. Kısa dönemde yapısal faktörler veri kabul edildiği için, büyüme oranları ve reel kur endeksindeki hareketlerin cari işlemeler dengesi üzerinde nasıl ve niçin bir dizi ikilem ve açmaza yol açtığı konusu irdelenmiştir.

Uz (2010) çalışmasında, döviz kuru, kamu ve özel tasarrufların cari işlemler dengesi üzerindeki uzun ve kısa dönem etkilerini ARDL yöntemiyle incelemiş ve döviz kurunun hem kısa hem de uzun dönem de önemli bir etkisinin olduğu sonucuna varmıştır. 
Bolat, Belke ve Aras (2011), 1998:1-2010:4 döneminde Türkiye'de ikiz açık hipotezinin (bütçe ve cari işlemler açığı arasındaki ilişkiyi) geçerliliğini incelemişlerdir. $\mathrm{Bu}$ iki değişken arasındaki kısa ve uzun dönem ilişkileri incelemek amacıyla sınır testi uygulanmıştır. Sonuçlar, uzun dönemde bu değişkenler arasında bir ilişkinin olmadığını, ancak kısa dönemde kuvvetli bir pozitif ilişkinin bulunduğunu belirlemişlerdir.

Canıdemir vd, (2011) Türkiye'de cari açığın yapısal ve dönemsel belirleyicilerini inceleyen ve 1989-2010 yılları arası çeyrek verilerini kullandıkları çalışmalarında, tamamen uyarlanmış en küçük kareler yöntemiyle (FMOLS) yaptıkları analizde, bütçe açığının, reel kurdaki ve ithalattaki artışın cari açığı arttıran en önemli değiş̧kenler olduğunu tespit etmişlerdir. Ayrıca cari açığın kendisinin daha sonraki dönemlerde kalıcı olduğunu ve özel tüketim harcamaları ve sermaye girişlerinin cari açığ artırdığını belirlemişlerdir.

Kayıkçı (2012), Türkiye'de 1987-2009 döneminde cari işlemler dengesi belirleyicilerini VAR yöntemiyle incelemiş, enflasyonun cari dengeyi pozitif yönde, büyüme, dışa açıklık, petrol fiyatları ve reel döviz kurundaki artışın ise negatif yönde etkilediği bulgularına ulaşmıştır.

Bayrak ve Esen (2012), Türkiye'de bütçe dengesi ile cari işlemler dengesi arasındaki ilişkileri, 1975-2010 dönemi arasında yıllık verileri ile Johansen eşbütünleşme ve hata düzeltme modelini uygulayarak araştırmışlardır. Elde edilen ampirik sonuçlara göre, bütçe açıkları ile cari işlem açıkları arasında kısa ve uzun dönemli bir ilişki olduğu sonucuna varılmıştır. $\mathrm{Bu}$ sonuçlar, Geleneksel Keynesyen Yaklaşımı desteklerken; Ricardocu Denklik Yaklaşımını reddetmiştir.

Göçer (2013), Türkiye'de cari işlemler açı̆̆ının nedenlerini ve finansman kalitesini VAR modeli, Johansen ve VEC yöntemleriyle, 1996-2012 y1lı verilerini kullanarak analizini yapmış ve Türkiye'de cari açığın zayıf formda sürdürülebilir olduğunu tespit etmiştir.

Keskoğlu, Yıldırım ve Çeştepe (2013) çalışmalarında, cari açığın belirleyicilerini, 1999-2009 döneminde, 28 OECD üyesi ülkenin verilerini kullanarak, panel VAR yaklaşımı ile tespit etmişlerdir. Cari açığın mikro ve makro nitelikli belirleyicilerinden ekonomik büyüme, faiz oranı, bütçe açığı ve döviz kuru ekonometrik açıdan anlamlı bulunmuştur. Yapılan analiz sonuçlarına göre, büyüme, faiz oranı ve bütçe açığı değiş̧kenlerinin cari açık üzerinde orta vadeli düşük bir etkiye sahip oldukları ve döviz kurunun herhangi bir etkiye sahip olmadığı tespit edilmiştir.

Fotourehchi vd, (2013) 1980-2011 dönemi için SUR yöntemini kullandıkları ve Türkiye ve İran'ın cari işlemler dengesini inceledikleri çalışmalarında, Türkiye'nin cari işlemler dengesini üzerinde büyüme oranı ve bütçe açığının negatif bir etkisi olduğu sonucuna varmışlardır. 
Türkoğlu (2013), çalışmasında, cari açık, cari açık ve borçlanmanın sürdürülebilirliği; Türkiye'de cari açık sorunu ve bu açı̆̆ın nedenleri, etkileri ve cari işlemler dengesini sağlamaya yönelik politika uygulamalarına ve tedbirlere yer verilmiştir.

Cari açığın belirleyenleri üzerine yabancı yazında da çok sayıda ve farklı yöntemlerle gerçekleştirilen çalışmalar mevcuttur. Örneğin, Calderon, Chong ve Loayza (2000), 44 gelişmekte olan ülkenin 1966-1995 yılları arasındaki verileri ile cari açığın belirleyicilerini GMM (Genelleştirilmiş Momentler Yöntemi) dinamik panel veri yöntemi ile analiz etmişlerdir. Tasarruflar, yatırımlar, gelir, dışa açıklık oranı, reel efektif döviz kuru, dış ticaret hadleri, sanayileşmiş ülkelerin büyüme oranları ve uluslararası faiz oranlarının cari işlemler açığı üzerindeki belirleyiciliği test edilmiştir. Yapılan analizde, büyüme oranındaki artış dolayısıyla yatırımların tasarruflardan daha çok artmasının cari işlemler açığını artırdığı, sanayileşmiş ülkelerin büyüme oranındaki artışın, gelişmekte olan ülkelerin cari işlemler açığını azaltıcı yönde etkide bulunduğu, kamu ve özel sektör tasarruf oranlarındaki değişikliklerin cari açıkta küçük miktarda bir daralmaya sebep olduğu bulgularına ulaşmışlardır. Benzer sonuçları Freund ve Warnock'un (2005), yüksek gelirli OECD ülkeleri için yaptı̆̆ ç̧alışmada da bulmak mümkündür. 1980-2003 dönemi verileri kullanılarak yapılan çalışmada cari açıkla ekonomik büyümenin birlikte hareket ettiği ve kısa dönemli yüksek dış borç durumunda cari açığın büyümeyi ve döviz kurunu etkilediği ortaya çıkmıştır.

Chinn ve Prasad (2000), 1971-1995 yılları arasındaki dönemde 18 sanayileşmiş ve 71 gelişmekte olan ülkede cari işlemler dengesinin belirleyicilerini panel veri analizi ile test etmişlerdir. Elde etmiş oldukları bulgular sonucunda, orta vadeli dönemde kamu bütçe dengesi ve net yabancı varlık stoku ile cari işlemler dengesi arasında pozitif yönlü bir iliş̧inin var olduğu ifade edilmiştir. Ayrıca, gelişmekte olan ülkeler arasında yapılan analiz sonucunda söz konusu ülkelerde finansal derinleşme ile cari işlemler açığı arasında negatif bir ilişkinin varlığı tespit edilirken, dışa açıklık oranı ile cari işlemler açığı arasında pozitif bir ilişkinin varlığı tespit edilmiştir.

Bussiere, Fratzscher ve Muller (2004), 33 Avrupa ülkesinin ve 21 OECD ülkesinin 1980-2002 dönemindeki y1llık zaman serisi verilerini kullanarak mali bilanço, göreceli gelir ve göreceli yatırım pozisyonunun orta dönemde cari işlemleri belirlediğini bulmuştur. Sonuçlara göre kişi başına düşük gelire sahip ülkeler ve yüksek yatırım oranları cari açıkların artmasına neden olma eğilimindedir.

Aristovnik (2007), 17 orta doğu ve kuzey Afrika ülkelerinde 1971-2005 yılları arasında cari işlemler açığının kısa ve orta vadeli belirleyicilerini dinamik panel veri yöntemleri ile analiz etmiştir. Yapılan analiz sonucunda, söz konusu ülkelerde büyüme oranı, kamu harcamaları, dışa açıklık oranı, doğrudan yabancı sermaye yatırımları cari işlemler açığını artırıcı yönde etkide bulunurken, yatırımlar, OECD ülkeleri büyüme oranı ve göreceli gelir, cari işlemler açığını azaltmaktadır. 
Sobrino (2007), çalışmasında enflasyon hedeflemesinin cari hesaba etkisini enflasyon hedeflemesi yapan 19 ülke için 35 ylllık dengesiz panel analizi ile incelemiştir. Çalışma sonucunda enflasyon hedeflemesi stratejisinin cari işlemler açığını arttırdığını belirlemiştir. Çalışmasında, enflasyon hedeflemesi sonucunda, yatırım ve tüketimin artmasıyla kısa ve uzun dönem reel faiz oranlarının azalmasıyla cari açığın arttığını belirlemiştir. Ayrıca, orta vadede finansal açıklığın kısa dönemde ise büyüme oranını cari açığı arttırdığını bulmuştur.

Yang (2010), 1989-2009 döneminde, yükselen ekonomilerden sekiz Asya ülkesi için cari açığın uzun ve kısa dönem belirleyicilerini VAR modeli ve Johansen eşbütünleşme yöntemiyle incelemiştir. Bulguları uzun dönemde cari açığın belirleyicilerinin net yabancı varlık stoku ve dışa açıklık olduğunu, kısa dönemde cari açıktaki dalgalanmalarda bu değişkenlerin etkisinin az olduğunu ortaya koymuştur. Reel döviz kurunun ise hem kısa hem uzun dönemde cari açık üzerinde belirleyici etkisinin çok az olduğunu saptamıştır.

Das (2012), cari işlemler dengesini gelişmiş, yükselen ve gelişmekte olan ülke örnekleriyle, 1980-2011 dönemi için ayrıntılı olarak incelemiş̧tir. Dinamik Panel GMM yöntemini kullandığı bu çalışmasında, gelişmiş ülkeler için net yabancı varlıklar, döviz kuru istikrarı, dışa açıklık oranı ve cari işlemler dengesi arasında pozitif yönlü, emtia fiyatları, büyüme oranı ve reel efektif döviz kuru ile ise negatif yönlü bir ilişki olduğu sonucuna varmıştır. Yükselen ekonomiler açısından ise emtia fiyatları, büyüme oranı, dışa açıklık oranı ve finansal açıklığın cari işlemler dengesi ile pozitif, net yabancı varlıklar ve döviz kuru istikrar indeksi ile negatif yönlü bir ilişki tespit etmiştir.

\section{Veriler ve Ekonometrik Yöntem}

Bu çalışmada, Türkiye'de, cari açık büyüklüğünü etkileyen değişkenlerden krediler, bütçe açığı, dış ticaret hadleri, para arzı, reel kur, reel faiz oranı ve büyüme oranının olası kısa ve uzun dönemli etkileri ekonometrik yöntemlerle belirlenmeye çalışılmıştır. $\mathrm{Bu}$ ilişskilerin tahminlenmesinde, TCMB'nin Elektronik Veri Dağıtım Sistemi’nden (EVDS) sağlanan; 1998:1-2013:1 dönemi çeyrekli verileri kullanılmıştır. Modelde yer alan değişkenler şöyle tanımlanmıştır: 
Tablo: 1

Modelin Veri Seti

\begin{tabular}{|l|l|c|}
\hline Değişkenler & Değişkenlerin Açıklaması & Modele Katkısı \\
\hline cagdp* & Cari İşlemler Dengesinin GSYH'deki Payı (\%) & ---- \\
\hline cregdp* & Bankacılık Sektörünün Toplam Kredi Hacminin GSYH'deki Payı (\%) & + \\
\hline$g d p^{*}$ & GSYH Büyüme Oranı (\%) & + \\
\hline bagdp* & Bütçe Açı̆̆ının GSYH'deki Payı (\%) & + \\
\hline$d t h a d$ & Diş Ticaret Hadleri (\%) & $+/-$ \\
\hline$m 2 g d p^{*}$ & Para Arzının GSYH'deki Payı (\%) & + \\
\hline$r e$ & Reel Döviz Kuru (TL/\$) & + \\
\hline$r i r$ & Reel Faiz Oranı (\%) & + \\
\hline \multirow{2}{*}{ * Mevsimsel etkilerden arındırılmıştır. } & \\
\hline
\end{tabular}

Tablo: 1'de yer alan değişkenler, bu çalışmada cagdp'nin belirleyicileri olarak tanımlanmış ve bunlar arasındaki ilişkiler aşağıdaki eşitlik yoluyla tahminlenmiştir.

$c a g d p=\beta_{0}+\beta_{1} \operatorname{cregdp}+\beta_{2} g d p+\beta_{3} b a g d p+\beta_{4} d t h a d+\beta_{5} m 2 g d p-\beta_{6} r e+\beta_{7} r i r+\varepsilon_{t}$

1 no'lu eşitliğe göre; kredilerdeki artış, ekonomik birimlerin tüketim ve yatırım harcamalarını artırdığından ve bu harcamaların bir bölümü yabancı mal ve hizmetlere yöneldiğinden, cari açığı artırır. Yine büyüme oranındaki artış, toplam harcamaları, dolayısıyla ithal mal ve hizmetlere yönelik talebi ve cari açığı artıran bir etki yaratmaktadır. Bütçe açığı ve cari açık arasında da pozitif bir ilişki vardır. Zira Keynesyen görüş ikiz açıklar hipotezine istinaden bütçe açıkları ile cari işlemler açığı arasında güçlü bir korelasyon ilişkisini savunurken, bunu gelir harcama yaklaşımına ve Mundell-Fleming modeline dayandırmıştır (Erdinç, 2008: 211).

İhraç mal fiyatlarının ithal mal fiyatlarına oranını ifade eden dış ticaret hadleri ile cari denge arasındaki ilişki hem teoride, hem de ampirik çalışmalarda farklılaşabilmektedir. Obstfeld (1982), diş ticaret hadlerindeki kötüleşmenin, reel geliri azaltıp, tasarrufları artırarak cari işlemler dengesini iyileştirdiğini ifade etmektedir. Diğer taraftan, Harberger-Laursen-Metzler hipotezine göre, marjinal tüketim eğilimi sabitken, dış ticaret hadlerindeki bir iyileşme reel gelirin, dolayısıyla tasarrufların artması nedeniyle cari işlemler dengesinde bir iyileşmeye neden olmaktadır.(Oktar, Dalyancı, 2012: 5).

Diğer taraftan para arzındaki artış piyasa faiz oranını düşürerek, dışlama etkisiyle yatırımların ve dolayısıyla milli gelirin artmasına neden olur. Artan gelirin bir bölümü yine ithal mal ve hizmetlerin satın alınması amacıyla kullanılacağından, ithalatı ihracat sabitken- dolayısıyla cari işlemler açığını artırır. Bu açıdan para arzı artışı ile cari açık arasında pozitif bir ilişki söz konusudur. Reel faiz oranındaki artış ise, ülkeye yönelik yabancı sermaye girişlerini artırarak, ulusal paranın değer kazanmasına neden olur. Bunun sonucunda da ithal malların göreli ucuzluğu nedeniyle cari açık artar. Diğer taraftan, reel döviz kurunun yükselmesi, ihracatı özendirip, ithalatı kısıtladığından, cari açığı azaltan bir 
sonuç ortaya koyar. Ancak burada ihraç ve ithal mallarının bu fiyat değişimine duyarlılıkları da dikkate alınmalıdır.

Modelin analizinde ilk aşamada, değişkenlere ait serilerin durağanlıkları belirlenmiştir. Zaman serisi analizlerinde, değişkenler arasında anlamlı bir ilişkinin varlığı, serilerin birim kök (unit root) içermemesi yani durağan olmaları koşuluna bağlıdır. Durağan olmayan seriler arasında sahte regresyon ilişkisi olacağından, analiz sonuçları gerçek ilişkiyi yansıtmayacaktır (Gujarati, 1999: 726).

Değişkenlerin durağanlıkları test edildikten sonra, aralarındaki uzun dönemli ilişki eşbütünleşme (koentegrasyon) analizi ile değişkenler arasında eşbütünleşme ilişkisinin varlığ 1 , uzun dönemde bu değişkenlerin birlikte hareket ettiğinin göstergesidir. $\mathrm{Bu}$ amaçla, Johansen-Juselius (1990) testi uygulanmıştır. Uzun dönemli ilişkinin belirlenmesinden sonra, değişkenler arasında kısa dönemde denge değerinden sapmalar, Vektör Hata Düzeltme Modeli (Vector Error Correction Model/VECM) ile test edilmiştir. Çalışmada kullanılan VECM, (2) no'lu eşitlik kullanılarak tahminlenmiştir. Buna göre:

$$
\begin{aligned}
\Delta \text { cagdp }= & \beta_{0}+\sum \beta_{1} \Delta \text { cagdp }_{\mathrm{t}-\mathrm{i}}+\sum \beta_{2} \Delta \operatorname{cregdp}_{\mathrm{t}-\mathrm{i}}+\sum \beta_{3} \Delta \mathrm{gdp}_{\mathrm{t}-\mathrm{i}}+\sum \beta_{4} \Delta \text { bagdp }_{\mathrm{t}-\mathrm{i}}+\sum \beta_{5} \Delta \mathrm{dthad}_{\mathrm{t}-\mathrm{i}} \\
& +\sum \beta_{6} \Delta \mathrm{m} 2 \mathrm{gdp}_{\mathrm{t}-\mathrm{i}}-\sum \beta_{7} \Delta \mathrm{re}_{\mathrm{t}-\mathrm{i}}+\sum \beta_{8} \Delta \mathrm{rir}_{\mathrm{t}-\mathrm{i}}+\beta_{9} \Delta \operatorname{resid}_{\mathrm{t}-\mathrm{i}}+\varepsilon_{\mathrm{t}}
\end{aligned}
$$

resid hata düzeltme terimini, değişkenlerin önündeki $\Delta$ simgesi değişimi ve $\varepsilon$ hata terimini temsil etmektedir. Burada uzun dönem denkleminden elde edilen artığın bir gecikmeli değeri kısa dönem denkleme dâhil edilmiştir. Bu modelin çalışabilmesi için, söz konusu artığın bir gecikmeli değerini gösteren hata düzeltme teriminin katsayısının $\left(\beta_{9}\right)$ istatistikî açıdan anlamlı, 0 ile -1 arasında bir değer alması gerekir.

Tek denklem yaklaşımı kullanılarak tahmin edilen modelde, değişkenler arasındaki nedensellik ilişkileri de VAR analizi ile sınanmıştır. Sims (1980) tarafından geliştirilen ve Granger nedensellik testi modelini temel alan VAR modelinde her değişken, hem kendi hem de diğer değişkenlerin gecikmeli değerlerinin bir fonksiyonu olarak yazılmaktadır. Bunlar durağan seriler olduğundan, denklemler birinci derece VAR fonksiyonunu oluşturmaktadırlar (Enders, 1995: 294-297). VAR analizindeki önemli karar aşamalarından biri, modelde yer alan değişkenler arasında dinamik ilişkileri yansıtacak gecikme uzunluklarının belirlenmesidir. Bunun için, Akaike bilgi kriteri (AIC) ya da Schwarz bilgi kriteri (SC) ile optimum gecikme uzunlukları belirlenebilmektedir (Enders, 1995: 300-302).

VAR yaklaşımında: $\Delta Y_{t}=\alpha+\sum_{i=1}^{p-1} \Gamma_{i} \Delta Y_{t-i}+\Pi Y_{t-1}+\varepsilon_{t}$

$Y$ değişkenler vektörünü, $\alpha$ sabit terimler vektörünü, $p$ uygun gecikme sayısını $\Gamma$ ve $\Pi$ katsayılar matrislerini ifade etmektedir. Katsayı matrisi $\Pi$ uzun dönem ilişkiler hakkında bilgi verir. 


\section{Analiz Bulguları}

Analize konu modelde yer alan değişkenlerin durağanlığı ADF birim kök testi ile belirlenmiştir. Birim kök testi sabitli-trendsiz ve sabitli-trendli olmak üzere iki farklı model için uygulanmıştır. Her iki uygulama sonuçlarına göre (Tablo: 2), büyüme oranını temsil eden değişken düzeyde durağan iken, diğer değişkenler birinci farklarında durağan olarak belirlenmişlerdir. Başka bir deyişle, bu seriler I(1) olarak ifade edilebilirler.

Tablo: 2

\section{İlgili Değişkenlerin Durağanlık Test Sonuçları}

\begin{tabular}{|l|c|c|c|c|}
\hline \multirow{2}{*}{ Değişkenler } & \multicolumn{2}{|c|}{ Düzey Değerleri } & \multicolumn{2}{c|}{ Birinci Farklar } \\
\cline { 2 - 5 } & Sabitli-Trendsiz & Sabitli-Trendli & Sabitli-Trendsiz & Sabitli-Trendli \\
\hline cagdp & $-1.912069(0.3247)$ & $-2.999686(0.1409)$ & $-7.088094^{*}(0.0000)$ & $-7.029251^{*}(0.0000)$ \\
\hline cregdp & $2.604845(1.0000)$ & $-1,343091(0.8673)$ & $-3.654244^{*}(0.0074)$ & $-7.018741^{*}(0.0000)$ \\
\hline gdp & $-10.02525^{*}(0.0000)$ & $-9.805216^{*}(0.0000)$ & ---------- & ----------- \\
\hline bagdp & $-1.188608(0.2119)$ & $-6.159285^{*}(0.0000)$ & $-9.345235^{*}(0.0000)$ & --------- \\
\hline$d t h a d$ & $-2.070270(0.2572)$ & $-3.219486(0.0905)$ & $-8.596824^{*}(0.0000)$ & $-8.548460^{*}(0.0000)$ \\
\hline$m 2 g d p$ & $-0.470728(0.8892)$ & $-1.601948(0.7806)$ & $-6.360807^{*}(0.0000)$ & $-6.307858^{*}(0.0000)$ \\
\hline re & $-2.081489(0.2527)$ & $-2.165797(0.4992)$ & $-6.114085^{*}(0.0000)$ & $-6.187263^{*}(0.0000)$ \\
\hline rir & $-1.732593(0.4098)$ & $-2.579135(0.2911)$ & $-5.344149^{*}(0.0000)$ & $-5.372323^{*}(0.0002)$ \\
\hline$* \% 5$ anlamlılık düzeyinde durağanlığ1 temsil eder. & \\
\hline
\end{tabular}

Değişkenlerin durağanlıklarının belirlenmesi bu değişkenler arasında uzun dönemli bir ilişkinin varlığı açısından temel koşuldur. Eşbütünleşme kuramında dengeden kısa süreli sapmalar, ancak ilgili seriler arasında eşbütünleşme ilişkisi olduğunda giderilebilir. Durağan seriler modelde ortaya çıkabilecek sahte regresyon sorununu da ortadan kaldırmaktadır (Granger, 1986: 226). Bu çalışmada, Engle-Granger tarafından geliştirilen iki aşamalı eşbütünleşme testi uygulanmıştır. Bu testin ilk aşamasında (1) no'lu eşitlikte yer alan değişkenlerin durağan değerleri dikkate alınarak En Küçük Kareler (OLS) testi uygulanmıştır. Bu eşitlik, aynı zamanda, uzun dönemli ilişkiyi de yansıtmaktadır. Zira değişkenlerin birim kök özellikleri gereği durağan olduklarının saptanmış olması, aralarında uzun dönemli bir ilişkinin varlığını da kanıtlamaktadır. İkinci aşamada ise, OLS ile tahminlenen eşbütünleşme denkleminden elde edilen hataların durağanlıkları test edilmiştir. Test sonuçları hata teriminin durağan olduğu yönündeki hipotezi destekliyorsa, bu durumda modele konu olan seriler arasında uzun dönemli bir ilişkinin olduğundan söz edilebilir. 
Cari açığın belirleyicilerinin dikkate alındığı (1) no'lu eşitlik analiz edilirken, modele, incelenen dönemde yaşanan iki ekonomik krizi (2000 Kasım ve 2001 Şubat ile 2008 küresel krizleri) temsilen bir kukla değişken (dmy) eklenmiştir. Tablo: 3'de, söz konusu eşitliğin OLS tahmin sonuçları yer almaktadır.

Tablo: 3

Modelin Yapısı

\begin{tabular}{|c|c|c|c|c|}
\hline Değişkenler & Katsayılar & Std. Hata & t-ist. Değeri & Olasılık Değeri \\
\hline dbagdp & -0.168892 & 0.180672 & -0.934798 & 0.3544 \\
\hline dcregdp & 0.023194 & 0.083444 & 0.277963 & 0.7822 \\
\hline$d m y$ & 0.429971 & 0.855227 & 0.502756 & 0.6174 \\
\hline ddthad & 0.258612 & 0.117232 & 2.205991 & 0.0320 \\
\hline$g d p$ & 0.494354 & 0.185914 & 2.659040 & 0.0105 \\
\hline$d m 2 g d p$ & -0.060046 & 0.044759 & -1.341543 & 0.1858 \\
\hline dre & -2.200511 & 4.147229 & -0.530598 & 0.5980 \\
\hline drir & 0.008412 & 0.444688 & 0.018917 & 0.9850 \\
\hline$c$ & 0.935990 & 0.622557 & 1.503461 & 0.1390 \\
\hline $\mathrm{R}^{2}$ & \multicolumn{4}{|c|}{0.221281} \\
\hline $\mathrm{D}-\mathrm{W}$ ist. & \multicolumn{4}{|c|}{2.167858} \\
\hline F-ist. (prob.) & \multicolumn{4}{|c|}{$3.531485(0.004237)$} \\
\hline
\end{tabular}

İlgili modelin tahmin sonuçlarına göre, dış ticaret hadleri ve büyüme oranını temsil eden değişkenler istatistikî açıdan anlamlı; katsayı işaretleri de beklenen ile uyumludur. Buna göre, dış ticaret hadlerindeki 1 birimlik artış, cari açığı 0,26 birim artırırken; büyüme oranındaki 1 birimlik artış, cari açığı 0,49 birim artırmaktadır. $\mathrm{Bu}$ değişkenler dişında diğer değişkenlerin katsayı işaretleri beklenen ile uyumlu olsa da, istatistikî açıdan anlamlı bulunmadıkları için değerlendirilmemişlerdir. Tahminlenen modelin $\mathrm{R}^{2}$ değeri düşük olmakla birlikte, değişkenlerin tümünü dikkate alan $\mathrm{F}$ istatistik değeri anlamlı bulunmuş; ayrıca otokorelasyon sorununun da olmadığı belirlenmiştir.

İkinci aşamada ise, Tablo: 3 'de test edilen modelden elde edilen hata terimine (resid1) birim kök uygulanmıştır. Bu testin sonuçlarına göre (Tablo: 4), hata terimi düzeyde durağandır yani $\mathrm{I}(0)$ 'dır. Bu sonuç seriler arasında uzun dönemli bir ilişkinin, dolayısıyla, serilerin eşbütünleşik olduğunu göstermektedir.

Tablo: 4

Eşbütünleşik Modelin Hata Teriminin Durağanlık Test Sonuçları

\begin{tabular}{|c|c|c|c|}
\hline \multirow{2}{*}{ Değişken } & \multicolumn{2}{|c|}{ Düzey Değerleri } & \multirow{2}{*}{ Bütünleşme Derecesi } \\
\cline { 2 - 3 } & Sabitli-Trendsiz & Sabitli-Trendli & \\
\hline residl & $-8.135122(0.0000)$ & $-6.263991(0.0000)$ & $\mathrm{I}(0)$ \\
\hline
\end{tabular}

Eşbütünleşme ilişkisinin belirlenmesinde kullanılan bir diğer test Johansen eşbütünleşme testidir. Bu yöntemde, aynı dereceden durağan olan değiş̧kenler arasında en 
az bir eşbütünleşik vektörün olması gerekir. Modelimiz ikiden fazla değişkenkenden oluştuğundan, birden fazla sayıda eşbütünleşme vektörünün olma olasılığg da vardır. $\mathrm{Bu}$ testin uygulanabilmesi için AIC ve SC bilgi kriterlerine göre uygun gecikme uzunluğu iki olarak belirlenmiş ve değişkenler iki gecikme değerlerine göre tahminlenmiştir. Yapılan test sonuçları Tablo: 5'de verilmiştir.

Tablo: 5

\section{Johansen Eşbütünleşme Testi Sonuçları}

\begin{tabular}{|c|c|c|c|c|c|}
\hline \multicolumn{2}{|c|}{ Eșbütünleșik Vektör Sayısı } & \multicolumn{2}{|r|}{ İz Testi } & \multicolumn{2}{|c|}{$\lambda$ - Maximum Testi } \\
\hline$H_{0}$ & $H_{1}$ & Istatistik & Kritik Değer (Prob.) & Istatistik & Kritik Değer (Prob.) \\
\hline$r=0$ & $\mathrm{r} \geq 1$ & 281.6661 & $208.4374(0.0000)$ & 76.13553 & $58.43354(0.0016)$ \\
\hline $\mathrm{r}=1$ & $r \geq 2$ & 209.2793 & $189.5991(0.0002)$ & 60.58047 & $52.36261(0.0057)$ \\
\hline $\mathrm{r}=2$ & $r \geq 3$ & 141.6813 & $152.7536(0.1582)$ & 32.93452 & $40.95680(0.1383)$ \\
\hline
\end{tabular}

Tablo: 5'deki sonuçlara göre, değişkenler arasında \%5 anlamlılık düzeyinde eşbütünleşmenin olmadığı yönündeki $\mathrm{H}_{0}$ hipotezi reddedilerek, en az iki eşbütünleşik vektörün olduğu yönündeki hipotez kabul edilmiştir. Buna göre, ilgili seriler arasında uzun dönemli ilişkiden söz edilebilir.

Değişkenler arasında uzun dönemli bir ilişki belirlenmiş olmasına rağmen, eşbütünleşme ilişkisinin tahmininde durağan olmayan serilerin farklarının alınması nedeniyle ortaya çıkan bilgi kaybı, kısa dönemde denge değerinden sapmalara yol açabilir. $\mathrm{Bu}$ sapmaların ne kadar sürede düzeltildiği VECM ile belirlenmektedir. Burada uygun gecikme uzunluğuna göre belirlenen model, eşbütünleşik modelden elde edilen hata düzeltme teriminin (resid2) bir dönem gecikmeli değeri eklenerek tahminlenmiştir. Hata düzeltme teriminin katsayısının istatistikî açıdan anlamlı, 0 ile -1 arasında bir değer alması gerekir. Katsayının negatif bir değer alması, dengeden sapma olduğunda uzun dönemde tekrar dengeye yaklaşılacağını göstermektedir.

Tablo: 6

VECM Yapısı

\begin{tabular}{|c|c|c|}
\hline Bağımlı Değişken & Bağımsız Değișken & Katsayı (t-ist.) \\
\hline \multirow{10}{*}{ dcagdp } & resid2 $2_{t-1}$ & $-0.106311(-7.49932)$ \\
\hline & dbagdp & $-0.191799(-1.028647)$ \\
\hline & dcregdp & $0.019296(0.226506)$ \\
\hline & ddthad & $-0.246640(-2.039593)$ \\
\hline & $d m 2 g d p$ & $-0.051054(-1.072252)$ \\
\hline & $d m y$ & $-0.354485(-0.418737)$ \\
\hline & dre & $-1.734261(-0.406172)$ \\
\hline & drir & $0.046999(0.103212)$ \\
\hline & $g d p$ & $-0.470081(-2.419770)$ \\
\hline & $c$ & $0.861547(1.316095)$ \\
\hline
\end{tabular}


Tablo: 6'da yer alan VECM sonuçlarına göre, hata düzeltme katsayısı $-0,106$ olarak tahminlenmiştir. Bu katsayı istatistikî açıdan anlamlı ve 0 ile -1 arasındadır. $\mathrm{Bu}$ koşul sağlandığından, VECM'in çalıştığı söylenebilir. Buna göre, bağımsız değişkenlerin neden olduğu cari açık dengesizliğinin \%10,6'sı, bir dönem içerisinde ortadan kalkmakta ya da düzeltilerek, tekrar eski denge düzeyine ulaşmaktadır.

Modelde yer alan değişkenlerin durağan ve eşbütünleşik bir yapıda olmaları, nedensellik testlerinin VECM'e göre uygulanmasına neden olmuştur. (2) no'lu eşitlikte de görüldüğü üzere, her bir değişkenin birinci dereceden farkı bağımlı değişken olarak; aynı zamanda da yine her değişkenin gecikmeli değerleri bağımsız değişken olarak, eşbütünleşme denkleminden elde edilen hata düzeltme terimi $(E C)$ ile birlikte tahminlenmiştir. Bu testin sonuçları Tablo: 7'de yer almaktadır.

Tablo: 7

VECM Granger Nedensellik Testi Sonuçları

\begin{tabular}{|l|c|}
\hline Ho: & Olasılık Değeri $(\boldsymbol{p})$ \\
\hline bagdp, cagdp'nin Granger nedeni değildir. & 0,0287 \\
\hline rir, cagdp'nin Granger nedeni değildir. & 0,0070 \\
\hline re, cagdp'nin Granger nedeni değildir. & 0,0108 \\
\hline dthad, cagdp'nin Granger nedeni değildir. & 0,0119 \\
\hline gdp, cagdp'nin Granger nedeni değildir. & 0,0413 \\
\hline cagdp, bagdp'nin Granger nedeni değildir. & 0,0475 \\
\hline
\end{tabular}

Modelin anlamlı sonuçlar verebilmesi için bağımsız değişkenlerin katsayılarının ya/ya da hata düzeltme teriminin katsayısının istatistikî açıdan anlamlı olması gerekir. Katsayılar anlamlı ise, "bağımsız değişken bağımlı değişkenin Granger nedeni değildir" şeklindeki boş hipotez reddedilmektedir. Tablo: 7'de ki sonuçlar anlamlılık düzeyi dikkate alınarak oluşturulmuş; olasılık değerine göre anlamlı bulunmayan ilişkilere yer verilmemiştir. Buna göre, modelin bağımsız değişkenlerinden biri olan bagdp ile bağımlı değişken cagdp arasında çift yönlü; rir, re, dthad ve gdp ile cagdp arasında ise tek yönlü (örneğin, rir'den cagdp'ye doğru) nedensellik ilişkisi belirlenmiştir.

\section{Sonuç}

Bu çalışmada, 1998:1-2013:1 dönemi çeyrekli verileri kullanılarak, Türkiye'de cari açığı etkileyen değişkenler analiz edilmiştir. Özellikle, enerji kaynaklarına yönelik dışa bağımlılığın yüksek olması nedeniyle, bu büyüklükle ilgili değişkenlerin baskınlığı dikkate alınarak, bunlar model dışında tutulmuştur. Modelin tahminlenmesi sonucu elde edilen ampirik sonuçlara göre, cari açık değişkeni ile bunun belirleyicileri arasında kısa ve uzun dönemli bir ilişkinin olduğu sonucuna ulaşılmıştır. Ancak ilgili değişkenlerden sadece büyüme oranı ve dış ticaret hadlerini temsil eden değişkenlerin katsayıları beklenen yönde bir katkı sağlarken, istatistikî olarak da anlamlı bulunmuşlardır. Buna göre, dış 
ticaret hadlerindeki 1 birimlik artış, cari açığı 0,26 birim artırırken; büyüme oranındaki 1 birimlik artış, cari açığı 0,49 birim artırmaktadır.

Kısa dönemde dengeden sapmaların ortaya çıkması durumunda, VECM'e göre, bağımsız değişkenlerin neden olduğu cari açık dengesizliğinin \%10,6'sı, bir dönem içerisinde ortadan kalkmakta ya da düzeltilmektedir. Değişkenlerin durağan ve eşbütünleşik bir yapıya sahip olmaları nedeniyle aralarındaki nedensellik ilişkisi VECM (Granger Nedensellik) ile test edilmiş; bagdp ile cagdp arasında çift yönlü; rir, re, dthad ve gdp ile cagdp arasında ise tek yönlü (örneğin, rir'den cagdp'ye doğru) bir nedensellik ilişkisi belirlenmiştir.

Modelin analizi ile elde edilen sonuçlar, son dönemde toplumda birçok kesimin cari açığın en önemli nedeni olarak algıladığı kredilere yönelik sınırlamaların, bu sorunun azaltılması hususunda yeterli olamayacağını göstermesi açısından önemlidir. Cari açık büyüklüğünü etkileyen değişkenler birlikte değerlendirildiğinde, parasal büyüklükleri temsil eden değişkenlerin etkilerinin zayıf olduğu söylenebilir. Politika yapıcıların cari açığın azaltılması ya da sürdürülebilmesine yönelik politik önermelerde bulunurken, bu değişkenler arasındaki nedensellik ilişkilerini ve etkileşimlerini dikkate almaları daha etkin sonuçlara ulaşılmasını sağlayacaktır.

\section{Kaynakça}

Aristovnik A. (2007), "Short- And Medium- Term Determinants of Current Account Balances in Middle East and North Africa Countries", William Davidson Institute Working Paper, The University of Michigan, No. 862, March.

Bayrak M. \& Ö. Esen (2012), "Bütçe Açıklarının Cari İşlemler Dengesi Üzerine Etkileri: İkiz Açıklar Hipotezinin Türkiye Açısından Değerlendirilmesi”, Ekonomik Yaklaşım, Cilt: 23, Say1: 82, 23-49.

Bolat S. \& M. Belke \& O. Aras (2011), "Türkiye'de İkiz Açık Hipotezinin Geçerliliği: Sinır Testi Yaklaşımı”, Maliye Dergisi, Sayı 161.

Bussiere M. \& M. Fratzscher \& G.J. Muller (2004), “Current Account Dyamics In OECD And EU Acceding Countries An Intertemporal Approach", European Central Bank Working Paper Series, No. 311.

Çakman, K. \& U. Çakmak (2007), "Cari İşlemler Açığı, Net Sermaye Hareketi, Kur Değişim Hızı ve Reel Kur Endeksi: Bağlamdaki İkilimlerin Bir Analizi”, Finans Politik \& Ekonomik Yorumlar, 44 (511), 28-37.

Calderon C. \& A. Chong \& N. Loayza (2000), "Determinants of Current Account Deficits in Developing Countries", The World Bank Policy Research Working Paper, No. 2398. 
Canıdemir, S. \& R. Uslu \& D. Ekici \& M. Yarat (2011), “Türkiye’de Cari Açığın Yapısal ve Dönemsel Belirleyicileri”, Ekonomik Yaklaşım Kongreler Dizisi VII, Gazi Üniversitesi, Ankara.

Chinn, M. \& E.S. Prasad (2000), "Medium- Term Determinants of Current Accounts in Industrial and Developing Countries: An Emprical Exploration”, NBR Working Paper Series, No. 7581 .

Das, D.K. (2012), "Determinants of Current Account Imbalance in the Global Economy: A Dynamic Panel Analysis", MPRA Paper, No.42419.

Dornbusch, R. \& F. Fischer (1990), Macroeconomics, McGraw-Hill, International Editions.

Enders, W. (1995), Applied Econometric Time Series, John Wiley \& Sons.Inc., USA.

Erdinç Z. (2008), "İkiz Açıklar Hipotezinin Türkiye'de 1950-2005 Yı1ları Arasında Eşbütünleşme Analizi ve Granger Nedensellik Testi İle İncelenmesi”, Anadolu Üniversitesi Sosyal Bilimler Dergisi, 8(1), 209-222.

Erkılıç, S. (2006), “Türkiye’de Cari Açığın Belirleyicileri”, T.C. Merkez Bankası, İstatistik Genel Müdürlüğü, Uzmanlık Yeterlik Tezi, Ankara.

Fotourehchi, Z. \& A. Şahinöz \& D. Panahi (2013), "Comparison of Effective Factors on Current Account: A Case Study on Iran and Turkey”, Middle -East Journal of Scientific Research, 13, 50-55.

Freund, C.L. (2000), "Current Account Adjustment in Industrialized Countries", Board of Governers of the FED International Finance Discussion Papers, 692.

Freund, C. \& F. Warnock (2005), "Current Account Deficits in Industrial Countries: The Bigger They Are, The Harder They Fall?", in R. Clarida (Ed.): G7 Current Account Imbalances: Sustainability and Adjustment, The University of Chicago Press.

Göçer İ. (2013), “Türkiye’de Cari Açığın Nedenleri, Finansman Kalitesi ve Sürdürülebilirliği: Ekonometrik Bir Analiz”, Eskişehir Osmangazi Üniversitesi IIIBF Dergisi, 8(1), 213242.

Gujarati, D.N. (1999), Essentials of Econometrics, Irwin/McGraw-Hill, 2nd. Edition, Boston.

Johansen, S. \& K. Juselius (1990), "Maximum Likelihood Estimation and Inference on Cointegration with Application to the Demand for Money", Oxford Bulletin of Economic and Statistics, $52,169-210$.

Kara, H. (2012), “Küresel Kriz Sonrası Para Politikası”, TCMB Çalışma Tebliği, No: 12/17, $<$ www.tcmb.gov.tr/research/discus/2012/WP1217.php>.

Kayıkçı, F. (2012), "Determinants of Current Account Balance in Turkey: Vector auto regression (VAR) Approach”, African Journal of Business Management, Vol. 6(17) 5725-36.

Keskoğlu, F. \& E. Yıldırım \& H. Çeştepe (2013),"Cari Açığın Belirleyicileri: 28 OECD Ülkesi İçin Panel VAR Analizi”, Ekonomik ve Sosyal Araştırmalar Dergisi, Cilt: 992, 9, 15-34.

Labonte, M. (2005), “Is the U.S. Current Account Deficit Sustainable?”, CRS Report for Congress, 13. 
Obstfeld, M. (1982), “Aggregate Spending and the Terms of Trade: Is There a Harberger-LaursenMetzler Effect?", Quarterly Journal of Economics, 97, 251-70.

Oktar, S. \& L. Dalyanc1 (2012), "Dış Ticaret Hadlerinin Cari İşlemler Dengesi Üzerindeki Etkisi: Türkiye Örneği”, Marmara Üniversitesi İ.İ.B.F. Dergisi, C.XXXIII, Sayı: II, 1-18.

Sims, C. (1980), “Macroeconomics and Reality”, Econometrica, 48 (1), 1-48.

Sobrino, R Cesar (2007), "The effects of Inflation Targeting on the Current Account: An Empirical Approach”, Department of Economics West Virginia University Working Paper, October.

Türkiye Cumhuriyet Merkez Bankası (TCMB) (1998-2011), Elektronik Veri Dă̆ıtım Sistemi (EVDS), <http://evds.tcmb.gov.tr/>.

Türkoğlu H. (2013), "Türkiye'de Cari Açık Sorunu: Nedenleri, Etkileri ve Uygulanabilecek Politikalar", İzmir Siyasal ve Ekonomik Araştırmalar Merkezi, <www.izsem.net>.

Uz, İ. (2010), "Determinants of Current Account: The Relation Between Internal and External Balances in Turkey", Applied Econometrics and International Development, Vol. 10-2, 115-26.

Yang, L. (2010), “An Empirical Analysis of Current Account Determinants in Emerging Asian Economies”, Cardiff Business School Working Paper Series, E2011/10.

Yücel, Y. (2003), "Dynamics of the Current Account Of Balance of Payments In Turkey", 7. Iktisat Kongresi, ODTÜ, Ankara. 
Aydanur GACENER ATIŞ \& Fatih SAYGILI 